\title{
BILATERAL GIANT FIBROADENOMA OF THE BREAST: A CASE REPORT
}

\author{
Jasmine Stephanie Christian ${ }^{1}$, Putu Anda Tusta Adiputra ${ }^{2 *}$, INW Steven Christian ${ }^{2}$ \\ ${ }^{1}$ General Surgery Training Programme, Faculty of Medicine Udayana University, Sanglah General Hospital, \\ Denpasar, Bali. \\ ${ }^{2}$ Surgical Oncology Division, Department of Surgery, Faculty of Medicine Udayana University, Sanglah \\ General Hospital, Denpasar, Bali. *Correspondence: andatusta@unud.ac.id.
}

\begin{abstract}
Background: fibroadenoma of the breast is one of the ANDI (Aberration of the Normal Development and Involution of the Breast) groups. Benign breast disorders are common in females younger than 30 years, but such masses are not common in juvenile or pre-menarche age groups. The exact pathological diagnosis can be investigated after surgery. For treatment, surgical procedures are needed to remove the lump. Case: a 30-year-old girl visited the outpatient clinic with psychological distress due to the presence of lumps in her both breasts. The lumps have been growing bigger and bigger in the last 3 years. On the physical examination both breasts are huge. FNAB showed the interpretation of atypical ductal hyperplasia and excisional biopsy examination confirmed the presence of bilateral giant fibroadenoma of breast. In this patient, the treatment was carried out in two-staged surgery due to her initial rejection to undergo total breast lumps and tissue removal. Several lumps still remained in the right breast which was indicated for the second surgery. The following surgery was done to remove all of the lumps and breast tissue with reduction breast surgery. Conclusion: conducting breast surgery on the young girl or un-married is not easy as many physical and psychology problems should be considered. Therefore, conducting breast surgery, in this case, should be performed wisely as the recurrence of the lumps was still possible.
\end{abstract}

Keywords: multiple giant fibroadenoma, surgery, psychology.

\section{FIBROADENOMA RAKSASA BILATERAL PADA PAYUDARA: SEBUAH LAPORAN KASUS}

\author{
Jasmine Stephanie Christian ${ }^{1}$, Putu Anda Tusta Adiputra ${ }^{2 *}$, INW Steven Christian ${ }^{2}$ \\ ${ }^{1}$ Program Studi Ilmu Bedah, Fakultas Kedokteran Universitas Udayana, Rumah Sakit Umum Pusat Sanglah, \\ Denpasar, Bali. \\ ${ }^{2}$ Divisi Bedah Onkologi, Departemen Ilmu Bedah, Fakultas Kedokteran Universitas Udayana, Rumah Sakit \\ Umum Pusat Sanglah, Denpasar, Bali. *Korespondensi: andatusta@unud.ac.id.
}

\begin{abstract}
ABSTRAK
Latar Belakang: fibroadenoma payudara adalah salah satu kelompok ANDI (Aberration of the Normal Development and Involution of the Breast), yang mencakup spektrum luas dari penyakit payudara benigna. Gangguan payudara jinak umumnya terjadi pada wanita yang kurang dari 30 tahun, tetapi massa tersebut tidak umum ditemui pada kelompok usia remaja atau pra-menarche. Giant fibroadenoma didefinisikan sebagai benjolan berukuran lebih dari $5 \mathrm{~cm}$. Fibroadenoma dapat terjadi pada satu atau kedua payudara dan tumbuh perlahan. Prosedur bedah diperlukan untuk mengangkat massa. Diagnosis patologis dapat ditegakkan setelah operasi. Kasus: seorang wanita 30 tahun mengunjungi klinik rawat jalan dengan tekanan psikologis karena adanya benjolan di kedua payudaranya. Benjolan tumbuh semakin besar dalam 3 tahun terakhir. Pada pemeriksaan fisik, ditemukan massa di seluruh kuadran payudara kanan dan kiri dengan berbagai ukuran. Pemeriksaan
\end{abstract}


FNAB menunjukkan gambaran hiperplasia duktus atipikal, kecurigaan ke arah keganasan. Pemeriksaan biopsi eksisi mengkonfirmasi adanya fibroadenoma raksasa bilateral pada payudara. Pada pasien ini, dilakukan operasi dua tahap karena pasien menolak dilakukan operasi total kedua payudara. Beberapa benjolan masih tersisa di payudara kanan dan direncanakan untuk operasi kedua. Operasi selanjutnya dilakukan untuk mengangkat seluruh masa dan jaringan payudara. Simpulan: tindakan operasi payudara pada wanita muda yang belum menikah bukanlah hal yang mudah karena banyak masalah fisik dan psikologis yang harus dipertimbangkan. Oleh karena itu, melakukan operasi payudara, dalam hal ini, harus dilakukan dengan bijaksana karena kekambuhan masih dapat terjadi.

Kata kunci: fibroadenoma raksasa multipel, operasi, psikologi.

\section{INTRODUCTION}

Giant fibroadenoma of the breast is defined as a fibroadenoma larger than 5 $\mathrm{cm}^{1}$ which is most common find in young women. ${ }^{2}$ Fibroadenoma mamma is the one of the groups of ANDI (Aberration of the Normal Development and Involution of the Breast). ${ }^{3}$ ANDI is an all-encompassing term that is used to describe a wide spectrum of Benign Breast Disease. Fibroadenomas have previously been regarded as benign neoplasms, but should now be considered as an aberration of normal development. ${ }^{4}$

It may occur during the time of the normal development of the breast. Most normal development of both breasts are range up to 25 years of age. The breast has reached its major development by 20 years of age and will usually begin to undergo atrophic changes in the fifth decade of life. ${ }^{5}$ Benign breast disorders are common in females younger than 30 years, but such masses are not common in juvenile or premenarchal age groups. Giant fibroadenoma may occur in one or both breast and growing rapidly. Although most fibroadenomas are benign, the presence of a mass can cause considerable anxiety because of the concern for cancer. These benign tumors arise from the epithelium and stroma of the terminal duct-lobular unit. In one consecutive series of patients,
$44 \%$ of fibroadenomas occurred in postmenopausal women. ${ }^{6}$ For treatment, surgical procedures are needed to remove the lump. The exact pathological diagnosis can be investigated after surgery.

\section{CASE REPORT}

A 30-year-old un-married girl came with the psychological distress due to her both breast growing bigger and bigger in last 3 years as well as shown on the picture. Family history was not relevant. On the physical examination, both breasts are huge and swelling with multiple lumps varies in size and involving of the whole quadrant of the breast. Her right breast consists of ten lumps involving the whole quadrant of the breast with the size of the lumps are varies more than $5 \mathrm{~cm}$. The left breast consists of nine lumps involving of the whole quadrant. The lumps were solid, painless, and moveable. The skin over the both breasts were hyperpigmented and showed dilatation of peripheral vascular. Normal of breast nipple and wide pigmented areolar of the breast are also noted. In general, patient is wellbeing. The blood laboratory test is in normal limit. Chest x-ray shown normal, no evidence of lesion. Breast ultrasonography examination is not provided as well as mammography. There was no evidence of both axillary lymphadenopathies. 
Fine needle aspiration biopsy (FNAB) examination showed an interpretation for atypical ductal hyperplasia suspicious for malignancy. Incisional biopsy showed the result of bilateral fibroadenoma of breast. There was no evidence of malignancy. Patient underwent two-staged surgery due to the rejection of taking the whole lumps for may all breast tissue should be removed. So, several lumps of the right breast are still remained (Figure 1). Majority of normal breast tissue were removed during excision of the lumps. Normal breast tissue also being removed and the breast became flat. The surgery was stopped because patient dan family need to be informed. Patient was fully distressed and rejected any kinds of surgery later.

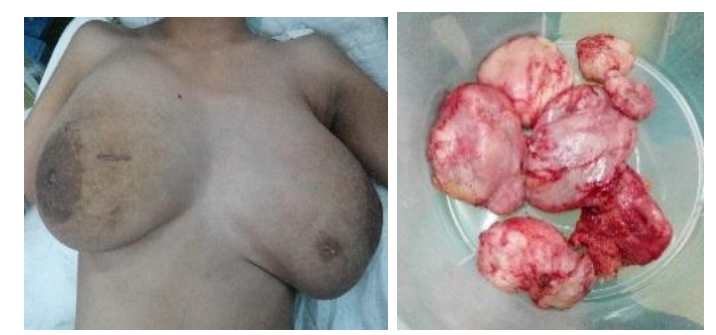

Figure 1. Clinical feature in the first presentation. The patient presented with bilateral giant fibroadenoma of breast (left) and already get an operation excisional biopsy on her right breast (right).

Three months later, she came to the hospital to make another surgery because her breast became bigger (Figure 2). The next surgery is to remove the all the lumps and breast tissue as well (reduction breast surgery) in the left breast. But the several lumps on the right breast still remain.

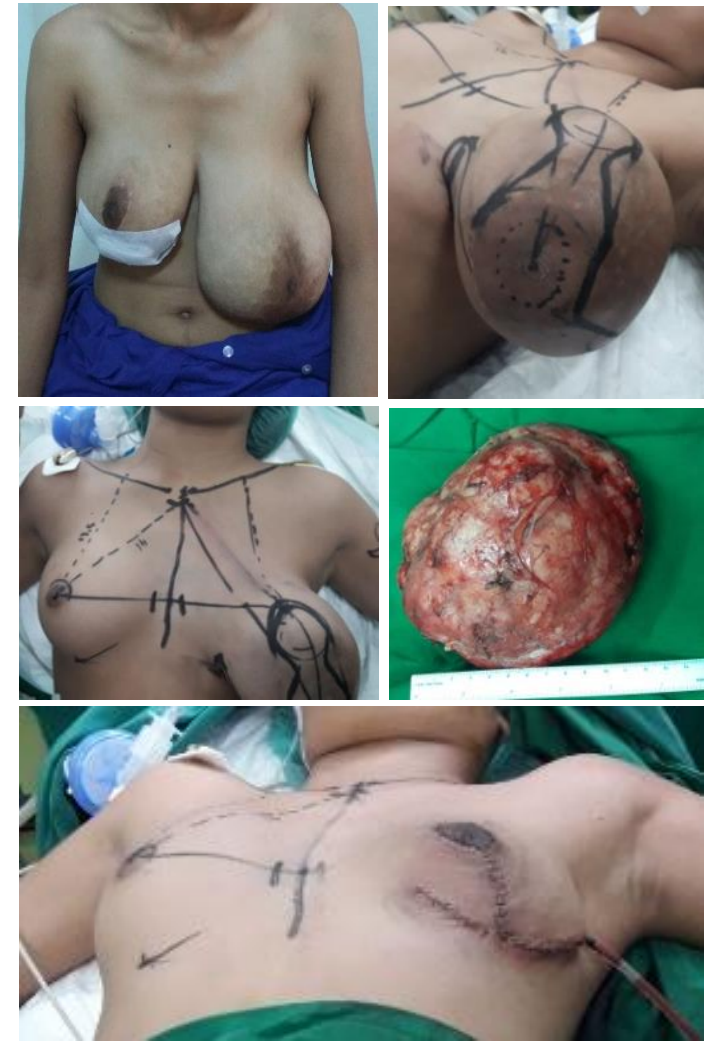

Figure 2. The lumps are getting bigger and worse after 3 months and next surgery is removed the all the lumps and breast tissue as well (reduction breast surgery) in the left breast.

\section{DISCUSSION}

The diagnosis and treatment of giant fibroadenoma can be a challenge for physicians. As fibroadenoma is considered a benign lesion without tendency to malignant degeneration, surgical treatment is generally not considered necessary to treat fibroadenoma. However, because of their size, giant fibroadenoma could result in local problems including breast asymmetry or deformity. It can become cosmetic problem for the affected patient with serious psychological effects. In fact, patient is often extremely concerned about potential cosmetic changes to the appearance of the breast after surgery. In the serious case, while some authors recommend reduction mammaplasty with inverted-incision technique to resect large fibroadenomas, others recommend using a 
more cosmetically appealing incision. ${ }^{7,8}$ The surgical management of giant fibroadenoma is still a matter of controversial debate in the literature. The necessity for excision is not disputed in patients presenting with breast deformity or suffering from local problems such as venous congestion, pressure necrosis and even occasionally ulcer.

\section{CONCLUSION}

Many problems should be considered before performing breast surgery in unmarried young girl. Although radical mastectomy will reduce the recurrence, the patient's satisfaction and psychological problems can be surfaced.

\section{REFERENCES}

1. Hille-Betz H, Klapdor R, Henseler H, et al. Treatment of Giant Fibroadenoma in Young Women: Results after Tumor Excision without Recontructive Surgery. Geburtshilfe Frauenheilkd. 2015;75:929-34.

2. Chang DS, McGrath MH. Management of benign tumors of the adolescent breast. Plast Reconstr Surg. 2007;120:13e-19e.

3. Robert E. Mansel. Management of Breast Pain. In: Harris JR, Lippman ME, Morrow M, et al. editor. Disease of The Breast. $5^{\text {th }}$ Edition. Philadelphia: Wolters Kluwer Health; 2014. p.51-7.

4. Purushotham AD, Britton P, Bobrow L. In: Borgen PI, Hill ADK, editors. Benign Breast Disease. Texas: Landes Bioscience; 2000. p.35-40.

5. Osborne MP, Boolbol SK. Breast Anatomy and Development. In: Harris JR, Lippman ME, Morrow M, et al. editor. Disease of The Breast. $5^{\text {th }}$
Edition. Philadelphia: Wolters Kluwer Health; 2014. p.3-14.

6. Bleicher RJ. Management of the Palpable Breast Mass. In: Harris JR, Lippman ME, Morrow M, et al. editor. Disease of The Breast. $5^{\text {th }}$ Edition. Philadelphia: Wolters Kluwer Health; 2014. p.29-37.

7. Biggers BD, Lamont JP, Etufugh CN, et al. Inframammary approach for removal of giant juvenile fibroadenomas. $J$ Am Coll Surg. 2009:208:e1-4.

8. Jacob MM. Application of reduction mammaplasty in treatment of giant breast tumour. $\mathrm{Br} J$ Plast Surg. 2000;53:265-6. 